\title{
"Linking resonant leadership, psychological ownership, and organizational commitment: The mediating role of employee empowerment"
}

\begin{tabular}{|c|c|}
\hline \multirow{5}{*}{ AUTHORS } & Mahfuz Judeh (iD) \\
\hline & Jassim Al-Ghasawneh (iD) \\
\hline & Hasan Al-Zu’bi (iD) \\
\hline & Abdul Hafaz Ngah (iD) \\
\hline & $\mathbb{R}$ \\
\hline \multirow{3}{*}{ ARTICLE INFO } & \\
\hline & organizational commitment: The mediating role of employee empowerment. \\
\hline & Problems and Perspectives in Management, 20(1), 153-163. \\
\hline DOI & \\
\hline & 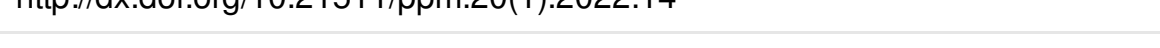 \\
\hline RELEASED ON & Wednesday, 02 February 2022 \\
\hline RECEIVED ON & Thursday, 02 December 2021 \\
\hline \multirow[t]{2}{*}{ ACCEPTED ON } & Wednesday, 19 January 2022 \\
\hline & $\left((c) \mathbf{E Y}_{\mathrm{EY}}\right.$ \\
\hline LICENSE & $\begin{array}{l}\text { This work is licensed under a Creative Commons Attribution } 4.0 \text { International } \\
\text { License }\end{array}$ \\
\hline JOURNAL & "Problems and Perspectives in Management" \\
\hline ISSN PRINT & $1727-7051$ \\
\hline ISSN ONLINE & $1810-5467$ \\
\hline PUBLISHER & LLC “Consulting Publishing Company "Business Perspectives" \\
\hline FOUNDER & LLC “Consulting Publishing Company "Business Perspectives" \\
\hline
\end{tabular}

NUMBER OF REFERENCES

43
NUMBER OF FIGURES

4
ニニシ

NUMBER OF TABLES

2

(C) The author(s) 2022. This publication is an open access article. 


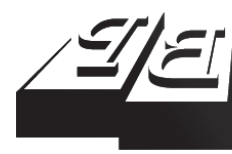

BUSINESS PERSPECTIVES

(2)

LLC "CPC "Business Perspectives"

Hryhorii Skovoroda lane, 10

Sumy, 40022, Ukraine

www.businessperspectives.org
Received on: $2^{\text {nd }}$ of December, 2021 Accepted on: $19^{\text {th }}$ of January, 2022 Published on: $2^{\text {nd }}$ of February, 2022

(C) Mahfuz Judeh, Jassim AlGhasawneh, Hasan Al-Zu'bi, Abdul Hafaz Ngah, 2022

Mahfuz Judeh, Ph.D., Professor President Consultant, Faculty of Business, Department of Business Administration, Applied Science Private University, Jordan. (Corresponding author)

Jassim Al-Ghasawneh, Ph.D., Assistant Professor, Faculty of Business, Department of Marketing, Applied Science Private University, Jordan.

Hasan Al-Zu'bi, Ph.D., Professor, Dean of Business Faculty, Department of Business Administration, Amman Arab University, Jordan.

Abdul Hafaz Ngah, Ph.D., Professor, Faculty of Business, Department of Economy and Social Development, Universiti Malaysia Terengganu, Malaysia.

Mahfuz Judeh (Jordan), Jassim Al-Ghasawneh (Jordan), Hasan Al-Zu'bi (Jordan), Abdul Hafaz Ngah (Malaysia)

\title{
LINKING RESONANT LEADERSHIP,
} PSYCHOLOGICAL OWNERSHIP, AND ORGANIZATIONAL COMMITMENT: THE MEDIATING ROLE OF EMPLOYEE EMPOWERMENT

\begin{abstract}
The purpose of the current study is to identify the antecedents of psychological ownership and organizational commitment since these constructs could influence different behavioral outcomes at the workplace, such as task performance, creativity, and organizational citizenship behavior. Through practicing resonant leadership, highly empowered employees are expected to have a deeper feeling of psychological ownership and more sense of commitment to an organization.

In this study, the direct relationships of resonant leadership on psychological ownership and organizational commitment via employee empowerment were investigated. Data were collected from 232 employees working at healthcare corporations listed on the Amman Stock Exchange in Jordan. Structural equation modeling was utilized to analyze the data. Results proposed that psychological ownership and organizational commitment were related to resonant leadership. Moreover, employee empowerment played a significant role, as a mediator between resonant leadership and psychological ownership and between resonant leadership and organizational commitment. Therefore, employees working with resonant leaders and having effective empowerment are expected to get higher levels of psychological ownership and tend to be highly committed to their organizations.
\end{abstract}

Keywords

JEL Classification

\section{INTRODUCTION}

Leaders can be considered the main key factor in making organizations successful and articulating the shared vision and mission to all followers. When leaders are equipped with emotional intelligence, the relationship between leaders and followers can drive any organization to produce better results (Ramos-Villarreal \& Holland, 2011). Resonant leaders, through utilizing their emotional intelligence, build an environment that motivates employee commitment to their organizations (Squires et al., 2010). Similarly, Wagner et al. (2013) demonstrated that there was a significant association between resonant leadership and commitment.

In general, psychological ownership and organizational commitment may depend on the treatment that employees get from their leaders. Organizations can have better performance through their committed employees who feel proud to be working with organizations. On the contrary, employees with low commitment tend to be associated with negative organizational outcomes. Furthermore, psychological own- 
ership may be affected by the leadership style and the employee empowerment level as well. Employee empowerment can be referred to as the delegation of power process by a manager to subordinates. Empowerment is attached to training subordinates, sharing information with them, and giving them the confidence to make decisions. The results of Hanaysha (2016) proved that empowerment has a significant effect on employee productivity.

The concept of employee empowerment has been an area of interest for scholars in the last three decades because it can be considered as a key factor in affecting subordinates' positive attitudes and behaviors in organizations. Mubarak et al. (2018) proved that there was a significant relationship between the authentic style of leadership, engagement, and empowerment.

Moreover, it was suggested that highly empowered individuals had a deeper feeling of psychological ownership and were more committed to the organization. This paper seeks to establish whether psychological ownership or organizational commitment is directly related to empowerment and indirectly related to resonant leadership. Most studies on resonant leadership have been done in the Western context. Therefore, there is a need to conduct studies on the precedents and effects of resonant leadership in the Jordanian context.

\section{LITERATURE REVIEW AND HYPOTHESES}

\subsection{Resonant leadership}

A lot of extensive and intensive studies addressing resonant leadership have been conducted during the last two decades. Most studies were related to nursing and health institutions. Resonant leadership has been rooted within the basis of emotional intelligence. Leaders having high levels of emotional intelligence can show that they are more effective through making use of resonant leadership attributes, although employees' emotions vary from time to time, and attempting to manage them is challenging. These leaders may guide followers' emotions, and guide their way of thinking and behaviors to encourage them to employ their emotions in meeting organizational objectives. They stimulate their subordinates to learn enthusiastically and be able to build relations with them, which can result in stronger positive feelings towards their organizations. Resonant leaders are ready to listen to their followers' grievances and negative feelings, care for them, and react empathetically.

The resonance between teams may be considered as the synchronization of concepts and passions among team members in the workplace
(Laschinger et al., 2014), especially during the processes or stages of restructuring and organizational change.

A resonant leader should be harmonic with her/ his subordinates, which results in the matching of their emotions and their way of thinking. In general, they can read others' minds and perceive their emotions, individuals, and teams, and accordingly, resonant leaders can build good relations with their subordinates and give hope for the future. Bawafaa (2014) proposed that resonant leaders can build empowering climates that improve job satisfaction.

Briefly, it can be stated that a leader who uses her/ his emotional skills to reflect on followers' emotions is considered a resonant leader. The resonant leaders can drive connections between them and enhance a synergistic environment in which followers are optimistic about the future and motivated to achieve common goals. In general, an effective leadership style can contribute to a higher degree of job satisfaction and organizational commitment, which, in turn, can lead to organizational success.

\subsection{Employee empowerment}

Reviewing the literature on empowerment, two perspectives are used when defining empowerment. A psychological perspective focuses on the 
employee's psychological state that is associated with intrinsic motivation and based upon employee perception that she/he has the authority to perform a job. A structural perspective indicates applying the organizational policies regarding delegating authority and providing autonomy at work.

From the psychological perspective, empowerment expresses the psychological state of subordinates. Empowerment is a psychological state concerning subordinates' perceptions (Forrester, 2000); subordinates should feel empowered when decisions are delegated to them, if not, they are not aware that they have been powered to take decisions.

Thomas and Velthouse (1990) stated that empowerment is referred to as increased task motivation categorized in four types: meaning, competence, self-determination, and impact. Meaningful actions entail all actions perceived by followers as contributing to the organizational goals and objectives. Empowering leaders have a significant effect on the followers' competence since they provide the followers with learning that will enhance their competence. Moreover, empowering leaders can have a significant effect also on self-determination and impact. Higher degrees of empowerment may result in followers' understanding of extended decision effect; therefore, improving the experience of self-determination.

Employee empowerment is a management exercise through which a manager delegates some of her/his authority to employees, supports them, equips them with knowledge and resources required, and allows them to make independent decisions regarding their delegated authority.

In general, empowerment is changing over time. In other words, the level of empowerment may vary due to the work environment. The review of the literature supports the claim that structural empowerment has an impact on the psychological empowerment of subordinates (Laschinger et al., 2001; Ahadi \& Turiman, 2014 ). The current study will investigate the structural perspective.

Employees need to have the feeling that they are accountable for their decisions. The level of empowerment varies depending on organizational culture, qualifications of subordinates, confidence in subordinates, and manager's wish to delegate authority. Empowerment assists subordinates realize the importance of their contribution to overall organizational goals. It also can be considered as a motivation tool because the empowering leader expresses her/his confidence in the subordinate's competence and give her/him a chance to have autonomy in work.

Empowered subordinates have been shown to improve efficiency and decrease costs; it also positively affects job satisfaction, job involvement, loyalty, performance, and better delivery (Nielsen \& Host, 2000). Employee empowerment can increase the level of loyalty to an organization and build a sense of belonging, which leads to better organizational performance. Taking a sample of 564 individuals, García-Juan et al. (2019) proved that employee empowerment was associated with organizational performance.

Peng (2013) suggested that psychological ownership theory can interpret organizational commitment among members in any organization. Depending on the psychological ownership concept, employees' attitudes and behaviors in the workplace can be predicted and interpreted.

\subsection{Psychological ownership}

The psychological ownership concept is based on an individual's sense of possession. Gardner et al. (2021) suggested that possession can be expressed as the conceptual core of psychological ownership. An individual can feel a psychological attachment to an object she/he does not own beyond the phenomenon of legal ownership. Psychological ownership can remain even in the absence of legal ownership. In the explanation of psychological ownership, Pierce et al. $(2001,2003)$ stated that the employee's sense of possession is the notional key of psychological ownership, and this is what differentiates it from commitment and identification.

In organizations, it is a psychologically experienced concept where an employee establishes possessive feelings towards her/his organization (Pierce et al., 2001). Pierce et al. (2001) added that psychological ownership can be described as the feelings of being psychologically attached to an 
object. Mayhew et al. (2007) expanded the notion of psychological ownership to incorporate both job-based and organizational-based psychological ownership.

According to Pierce et al. (2001, 2003), the motivational variables regarding psychological ownership include efficacy and effectance, self-identity, and having a sense of belonging. Efficacy and effectance in this connection are concerned with motivating employees through their needs to assess the surroundings, find rational solutions to problems with the perseverance to achieve the planned goals and accomplishments. When employees achieve the organizational goals, they are expected to feel a higher state of psychological ownership. Notwithstanding that an employee does not achieve some of the organizational goals; the cognitive-affective feel of psychological ownership is expected to exist.

Furthermore, the state of psychological ownership can be also a motivational factor, because individuals are inclined to express their self-identity in front of other people in a way to identify themselves. Moreover, the sense of belonging focuses on the emotional needs of individuals to have the acceptance and support from other members of a certain group. When they feel an organization is theirs, it becomes a part of their self-definition and identity. A sense of belonging may motivate employees to more positive organizational behaviors, which, in turn, can affect performance. Hence, psychological ownership can be described by employees who feel more effectual about achieving the organizational target, feel more accountable for achieving the target, and feel more loyalty and personal identification in this concern (Avey et al., 2012).

The psychological ownership concept is applicable even in the entrepreneurship context (DeTienne, 2010). Entrepreneurs commercialize the new idea, invest money and time in their venture. During the early stages of the entrepreneurship process, psychological ownership can be developed and enhanced (DeTienne, 2010). Entrepreneurs with psychological ownership feelings may act more responsibly for managing the venture.

Additionally, a high level of ownership feeling can satisfy employees' need for belonging (van Dyne
\& Pierce, 2004). The higher the level of the ownership feeling is, the more sense of belonging an individual will have.

Han et al. (2010) indicated that decision-making participation could influence ownership. Moreover, psychological ownership has significant relationships with some positive behaviors, for instance, knowledge sharing (Hameed et al., 2019) and organizational citizenship behavior (Gardner et al., 2021).

Avey et al. (2009) proved that strong psychological ownership feeling of employees towards their organizations can enhance the level of their commitment and can also lower the rate of turnover in their organization.

\subsection{Organizational commitment}

Organizational commitment can be described as a state of a member in an organization where she/ he displays feelings of loyalty to the job to meet the target. A committed member of the organization is expected to continue working with the same organization, protect its property, and contribute to the organizational goals (Meyer \& Allen, 1997). Furthermore, employees' commitment can be expressed as a type of obligation and attachment to the organization. A high degree of commitment in the workplace may reduce the rate of absenteeism, lower the turnover rate, and improve performance (Mathieu \& Zajac, 1990). Through understanding the role of commitment in the success of organizations, managers may direct all processes and activities more efficiently.

To enhance employee commitment, management should ensure that the physical and psychosocial work environment for the employees is adequate and effective. The provision of adverse working conditions can negatively influence employee commitment and job stability (Weiss, 1999; Danish et al., 2013). Accordingly, a good environment in the workplace can create a positive influence on members of the organization, boost levels of employee commitment, and enhance their job satisfaction. Finally, highly committed employees have positive attitudes towards their work, which is, in turn, reflected in their organizational behaviors and organizational performance. 


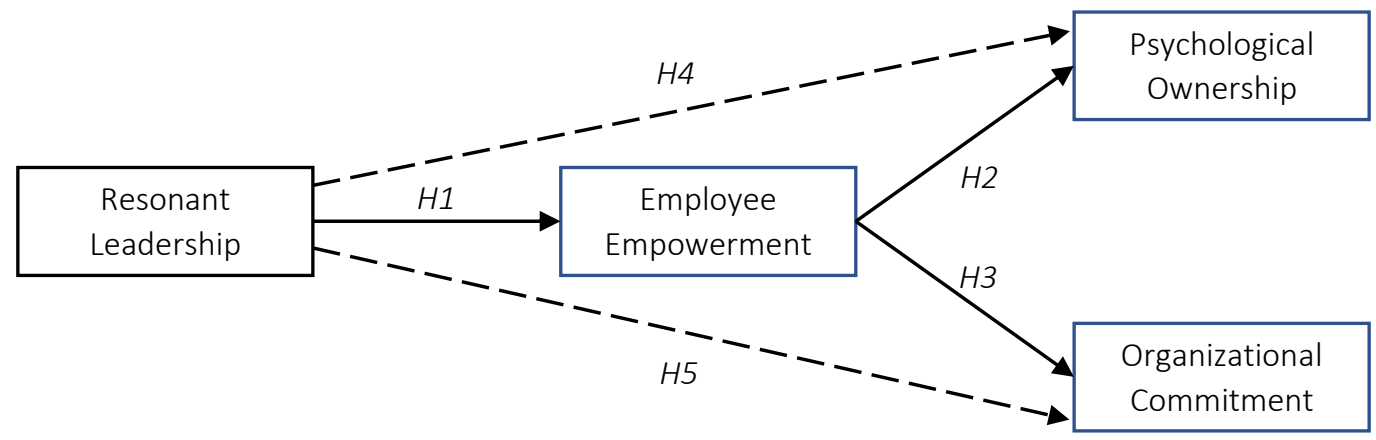

Figure 1. Theoretical framework

Meyer and Allen $(1991,1997)$ described three components of commitment in this regard: affective, normative, and continuance.

Affective commitment indicates the commitment that is pertaining to the emotional attachment, attachment to, and getting involved in the organization (Meyer \& Allen, 1997). An employee who shows a high degree of affective commitment tends to feel attached to and is expected to be pleased to be a member of the organization.

Normative commitment is based upon society's belief of obligation; therefore, an employee with a high level of normative commitment shows definite behavior developed on what she/he believes is right.

Continuance commitment can be described as the willingness of employees to continue working with the organization; this may be explained by the costs experienced when leaving the organization she/he works with. An employee with a high degree of continuance commitment shows a willingness to continue working with the organization.

Throughout the years, three accesses were adopted to discuss organizational commitment issues: commitment-related attitudes, commitment-related behaviors, and commitment-related effects. The commitment-related attitude focuses on the affective attachment to the organizational goals and to the organization she/he works with, while the commitment-related behaviors focus on the employee behavior which is attached to the strong motives and efforts excreted by the employee in work. Moreover, the commitment-related effects are associated with the positive effects of commitment on the results of the organization.
There is a certain influence of organizational commitment in the change management context in organizations. Darwish (2000) proved that organizational commitment might be an essential predictor for employees' low resistance or even nonresistance change management. In this connection, Iverson (1996) proposed that commitment was a very essential predictor of organizational change.

Borghei et al. (2010) indicated that empowerment was associated with commitment. Sabir and Khan (2011) suggested that all styles of leadership could be considered as one of the commitment dimensions. Wagner (2010) proved that resonant leadership can affect satisfaction and commitment.

Along with the theoretical literature, the present paper aims to assess the association of resonant leadership, empowerment, psychological ownership, and organizational commitment. Hence, the following hypotheses are shown in Figure 1.

H1: Employee empowerment is directly related to resonant leadership.

H2: Psychological ownership is directly related to employee empowerment.

H3: Organizational commitment is directly related to employee empowerment.

H4: Employee empowerment plays a mediation role between resonant leadership and psychological ownership.

H5: Employee empowerment plays a mediation role between resonant leadership and organizational commitment. 


\section{METHODS}

\subsection{Sample and data collection}

Participants in the study were employees selected from healthcare corporations listed in Amman Stock Exchange (2019) in Jordan. Questionnaires with a note to assure complete confidentiality were distributed to 400 employees and only 232 questionnaires were returned duly completed. The mean age of the sample chosen was 32.6, $51.7 \%$ of them were male, and $53.9 \%$ were married. Statements of the questionnaire were anchored on a seven-point Likert scale as choices of answers.

\subsection{Measures}

Employees filled out the questionnaires which included four variables. For resonant leadership, six items were adapted from Ferreira (2020) and Cummings et al. (2010). Employee empowerment was measured using six items of the instrument developed by Spreitzer (1995). Psychological ownership was rated by respondents using eight items from Avey et al. (2009). Organizational commitment was measured by the respondents using six items from Meyer and Allen (1997). Three demographic characteristics were assessed: gender, age, and tenure. Gender was assessed as a dichotomous variable, while age and tenure through responding in values and classifying in categories.

\section{DATA ANALYSIS}

\subsection{Demographic characteristics}

Table 1 showed that 40.9 percent of the total 232 participants were male. The age average for the whole sample was about 31.8. Moreover, 45.3 percent of the participants had less than an 11-year tenure of service.

Results from independent sample $t$-test and oneway ANOVA indicated that there were no relationships between each of the three demographic variables neither with psychological ownership nor with organizational commitment. In this case, it would be better to exclude demographic factors from analysis to avoid misinterpreting study results and conclusions.
Table 1. Demographic data

\begin{tabular}{|c|c|c|c|}
\hline \multicolumn{2}{|c|}{ Characteristics } & Number & $\%$ \\
\hline \multirow{2}{*}{ Gender } & $M$ & 95 & 40.9 \\
\hline & $\mathrm{F}$ & 137 & 59.1 \\
\hline \multicolumn{2}{|l|}{ Total } & 232 & 100.0 \\
\hline \multirow{5}{*}{ Age } & 26 and less & 97 & 41.8 \\
\hline & $27-33$ & 53 & 22.8 \\
\hline & $34-40$ & 44 & 19.0 \\
\hline & $41-47$ & 24 & 10.3 \\
\hline & 48 and above & 14 & 6.0 \\
\hline \multicolumn{2}{|l|}{ Total } & 232 & 100.0 \\
\hline \multirow{5}{*}{ Tenure } & 5 and less & 41 & 17.7 \\
\hline & $6-10$ & 64 & 27.6 \\
\hline & $11-15$ & 85 & 36.6 \\
\hline & $16-20$ & 23 & 9.9 \\
\hline & 21 and above & 19 & 8.2 \\
\hline \multicolumn{2}{|l|}{ Total } & 232 & 100.0 \\
\hline
\end{tabular}

\subsection{Descriptive statistics and Pearson correlations}

Table 2 represents the means, standard deviations, bivariate correlations, and reliability coefficients of all variables.

Table 2. Descriptive statistics, Pearson correlations, and reliability coefficients

\begin{tabular}{l|c:c:c:c:c:c}
\hline \multicolumn{1}{c}{ Variable } & Mean & SD & $\mathbf{1}$ & $\mathbf{2}$ & $\mathbf{3}$ & $\mathbf{4}$ \\
\hline 1. Resonant & 4.453 & 1.670 & $(.94)$ & $341^{* *}$ & $503^{* *}$ & $448^{* *}$ \\
2. Empowerment & 5.183 & .961 & & $(.85)$ & $442^{* *} 548^{* *}$ \\
3. Ownership & 4.925 & 1.361 & & & $(.89)$ & $582^{* *}$ \\
4. Commitment & 4.182 & 1.506 & & & $(.95)$ \\
\hline
\end{tabular}

Note: Alpha coefficients are represented in parentheses along diagonal; ${ }^{* *} p<.01$.

Alpha reliabilities ranged between 0.85 and 0.95 , which can be considered acceptable. All correlations are significant and proposed for further analysis.

\section{RESULTS}

Exploratory factor analysis resulted in four factors accumulating (67.589) percent of the whole variance. All item loadings as per the EFA ranged between 0.658 and 0.893 were acceptable as the level of factor loadings exceeded (0.40). Confirmatory factor analysis was utilized on the questionnaire statements to evaluate their factor loadings. The model fit of a four-factor measurement model factors (resonant leadership, employee empowerment, psychological ownership, and 


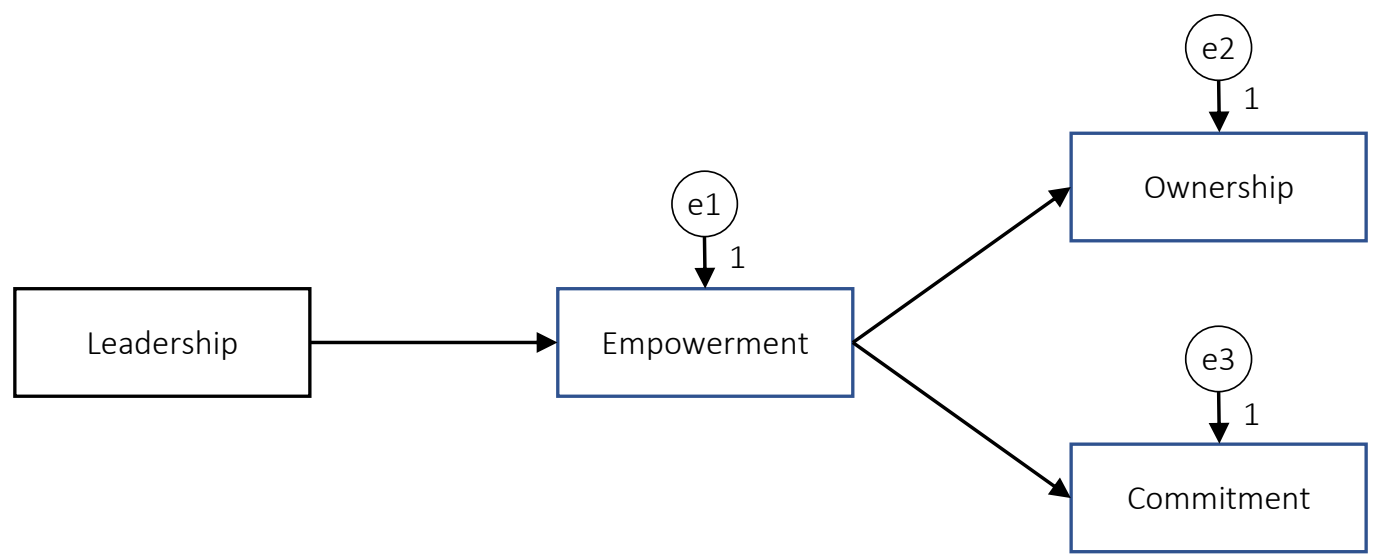

Figure 2. Fully mediated model (M-1)

organizational commitment) was matched with a one-factor model where the four factors were loaded on a single one. The four-factor model resulted in CMIN/DF (1.729) which was fit the data (Kline, 2005). Other results showed that CFI = (.951), TLI $=(.946)$, and RMSEA $=(.056)$. All these indices were acceptable fit. Furthermore, the single-factor model showed CMIN/DF (8.848), CFI $=(.492), \mathrm{TLI}=(.447)$, and RMSEA $=(.179)$, which indicated were inadequate fit. Since the four-factor model demonstrated a better fit, therefore, it was employed for further analysis. Hypotheses of the study can be tested by adding predicted paths to the measurement model without adding the indirect paths. Model 1 was designed assuming a full mediation of empowerment in the relationship between resonant leadership and psychological ownership and between resonant leadership and organizational commitment. Results of Model 1 showed that indices were unacceptable fit since $\mathrm{CMIN} / \mathrm{DF}=(27.128), \mathrm{CFI}=(.657), \mathrm{TLI}=$ (.314), and RMSEA $=(.336)$.
Thus, Model 2 was depicted in Figure 3 by adding two paths; the first one from resonant leadership to psychological ownership, and the second from resonant leadership to organizational commitment.

Results of Model 2 demonstrated good fit since $\mathrm{CMIN} / \mathrm{DF}=(2.303), \mathrm{CFI}=(.994), \mathrm{TLI}=(.966)$, and RMSEA $=(.075)$. However, when comparing the unstandardized direct relationship between resonant leadership and psychological ownership $(\beta=0.32 ; p<.01)$ with the unstandardized indirect relationship between the two variables $(\beta=0.08$; $p<.01)$ it was found that $\beta$ coefficient decreased, suggesting mediation, and partially supporting H4. Furthermore, when comparing the unstandardized direct relationship between resonant leadership and organizational commitment $(\beta=0.27$; $p<.01)$ with the unstandardized indirect relationship between the two variables $(\beta=0.14 ; p<.01)$ it was noticed that $\beta$ coefficient dropped down, suggesting mediation, and partially supporting H5. Although there was preliminary evidence that

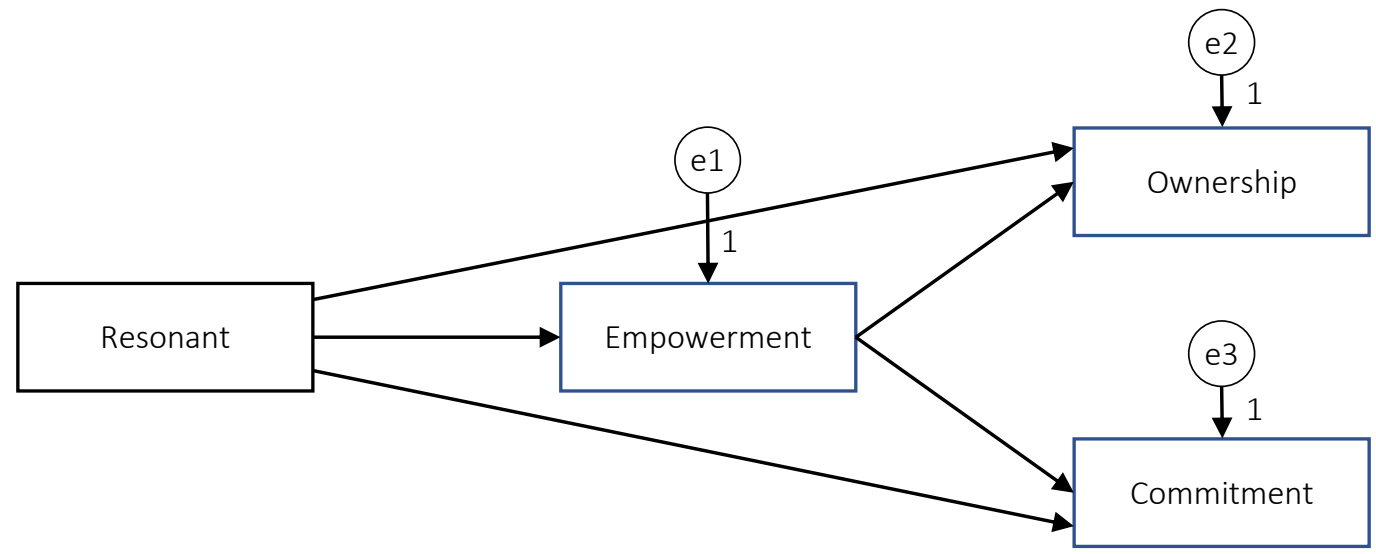

Figure 3. Partially mediated model (M-2) 


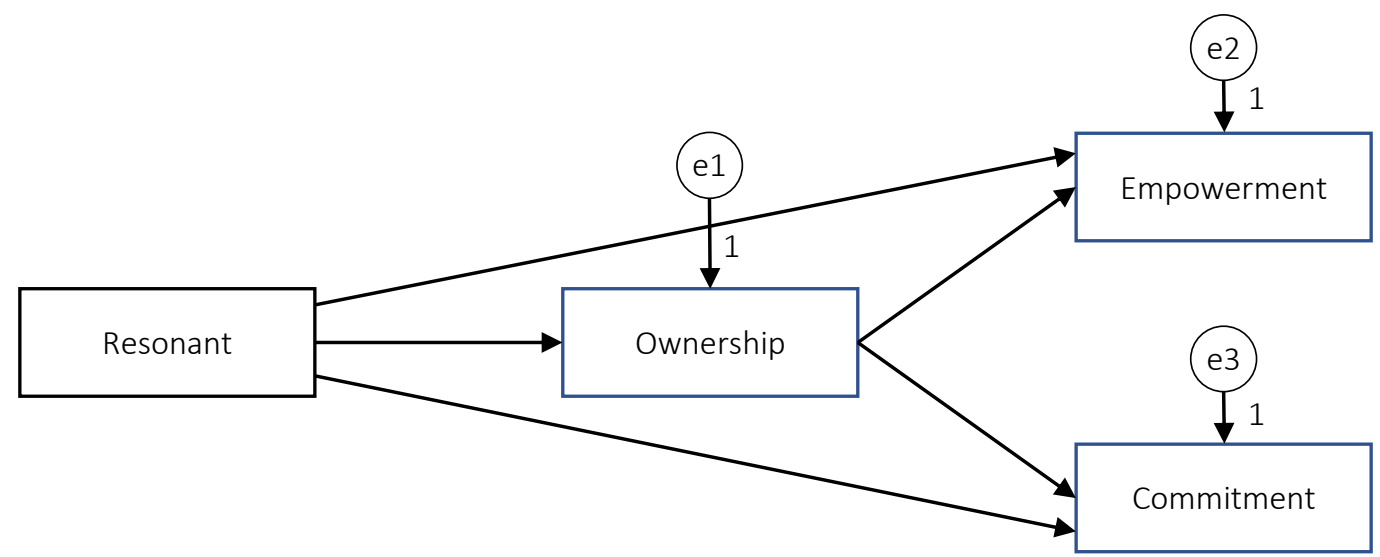

Figure 4. Alternative mediated model (M-3)

Model 2 was a good fit for data, it was probable that other paths could design a better model. An alternative model (Model 3) as shown in Figure 4 was presented by inserting psychological ownership as a mediator and empowerment as an independent variable to test if it can fit the data better.

The data fit of the alternative model (Model 3) was lower $(\mathrm{CMIN} / \mathrm{DF}=58.684$; $\mathrm{CFI}=.748$; $\mathrm{TLI}=.514$; RMSEA $=.500)$ than of M-2. Therefore, M- 3 was rejected and M-2 was adopted in the current study. Based on the best fit of data in Model 2 (Figure 3) and according to the output of the model, all direct paths supported $H 1, H 2$, and $H 3$. Employee empowerment was directly related to resonant leadership $(\beta=0.34 ; p<.01)$. Psychological ownership was directly related to employee empowerment $(\beta=0.31 ; p<.01)$, and organizational commitment was also directly related with engagement $(\beta=0.45 ; p<.01)$.

\section{DISCUSSION AND IMPLICATIONS}

Psychological ownership and organizational commitment may depend on the treatment that employees get from their leaders. Organizations can have better performance by employing the help of dedicated employees who are glad to be associated with their organization. Therefore, the current study has hypothesized that employee empowerment is directly related to resonant leadership (H1), ownership is directly related to employee empowerment (H2), and commitment is directly related to employee empowerment (H3). Empowering employees presents the mediation role between resonant leadership and ownership (H4). Employee empowerment serves also as a mediator between resonant leadership and organizational commitment (H5). Based on the structural equation modeling outputs, the study found that all direct paths support $H 1, H 2$, and $H 3$.

The positive relationship results between resonant leadership and empowerment were similar to the results of Bawafaa et al. (2015). Employees can get better access to information and knowledge required to do their tasks if their supervisors exhibit resonant leadership behaviors. Furthermore, leaders who exhibit emotional intelligence seem to be consistent with the emotions of others, utilize compassion, and efficiently express feelings to create better, trusting relationships, and foster an environment of enthusiasm that incites employees to effectively complete their tasks. The result concerning the positive relationship between employee empowerment and psychological ownership agreed with $\mathrm{Lu}$ et al. (2017). When employees establish possessive feelings towards their organizations, this feeling motivates them through their needs to assess the surroundings, find rational solutions to problems with the perseverance to achieve the planned goals and accomplishments. Likewise, when employees achieve the organizational goals, they are expected to feel a higher state of psychological ownership and this makes them more committed to their organizations because of this ownership feeling. Employee empowerment and organizational commitment have a positive relationship, according to AlKahtani et al. (2021), which explains that em- 
ployees' positive feelings and actions toward organizational goals and values contribute to organizational commitment.

Furthermore, the results of the current study found that employee empowerment significantly mediated the relationship between resonant leadership and the feeling of ownership. Resonant leaders are mature enough to know how to affect employees and use emotional intelligence to help and support their employees; this provides employees with a certain degree of confidence in themselves and in their leaders, which, in turn, lead to boost the psychological ownership inside them.

Finally, results found that employee empowerment mediated the relationship. Resonant leaders understand that utilizing emotional intelligence with employees can influence them and, in turn, lead to making them more committed to the job and the organizational goals.

Based on the above discussion, the current study theoretically contributes to the existing knowledge regarding the influence that resonant lead- ership has on employee empowerment and the influence that employee empowerment has on psychological ownership. Research findings enlighten the situation of organizational behavior in the Jordanian environment, especially the role of employee empowerment as mediation between resonant leadership and psychological ownership and between resonant leadership and organizational commitment.

As for the practical aspect, the current paper is expected to assist leaders and health institutions management to focus on following resonant leadership that influences both psychological ownership and commitment. Additionally, findings can make policymakers aware of the study findings that employee empowerment mediates the relationship between resonant leadership and psychological ownership and organizational commitment. Practical advantages are gained by organizations whose leaders follow a leadership style based on emotional intelligence to enhance good organizational behaviors, such as employee empowerment, psychological ownership, and commitment.

\section{CONCLUSION}

The current study aimed to describe the emotional intelligence and caring climate of practicing resonant leadership and its effect on different behavioral outcomes, such as employee engagement, psychological ownership, and organizational commitment. This study demonstrated that psychological ownership and organizational commitment positively correlated with resonant leadership. Moreover, the study proved that employee empowerment played a significant mediating role in these correlations.

Findings implied that employees are expected to be more committed to their organizations in the climate of resonant leadership when having adequate empowerment. Similarly, employees can have better feelings of psychological ownership in the climate of resonant leadership when they are adequately empowered. Therefore, it is important to encourage resonant leadership and increase the level of empowerment in healthcare organizations because this can lead to better organizational behavior. The study emphasizes the need for healthcare institutions in the context of Jordan in particular and the developing countries in general to adopt the necessary strategies to enhance the psychological ownership feeling and improve the sense of belonging to the organization.

\section{AUTHOR CONTRIBUTIONS}

Investigation: Hasan Al-Zu'bi.

Methodology: Mahfuz Judeh, Abdul Hafaz Ngah.

Project administration: Mahfuz Judeh.

Resources: Abdul Hafaz Ngah.

Software: Hasan Al-Zu’bi, Abdul Hafaz Ngah. 
Supervision: Jassim Al-Ghasawneh.

Validation: Mahfuz Judeh, Jassim Al-Ghasawneh, Abdul Hafaz Ngah.

Visualization: Hasan Al-Zu'bi.

Writing - original draft: Mahfuz Judeh.

Writing - review \& editing: Jassim Al-Ghasawneh.

\section{REFERENCES}

1. Ahadi, S., \& Turiman, S. (2014). Structural Empowerment and Organizational Commitment: The Mediating Role of Psychological Empowerment in Malaysian Research Universities. Journal of Asian Development Studies, 3(1), 44-65.

2. AlKahtani, N., Iqbal, S., Sohail, M., Sheraz, F., Jahan, S., Anwar, B., \& Haider, S. (2021). Impact of employee empowerment on organizational commitment through job satisfaction in four- and five- star hotel industry. Management Science Letters, 11(3), 813-822. http://dx.doi. org/10.5267/j.msl.2020.10.022

3. Amman Stock Exchange. (2020). Information. Amman, Jordan. (In Arabic). Retrieved May 18, 2021, from https://www.ase.com.jo/

4. Avey, J. B., Avolio, B., Crossley, C., \& Luthans, F. (2009). Psychological Ownership: Theoretical Extensions, Measurement, and Relation to Work Outcomes. Journal of Organizational Behavior, 30, 173191. Retrieved from https://digitalcommons.unl.edu/managementfac$\mathrm{pub} / 18$

5. Avey, J. B., Wernsing, T. S., \& Palanski, M. E. (2012). Exploring the process of ethical leadership: The mediating role of employee voice and psychological ownership. Journal of Business Ethics, 107(1), 21-34. http://dx.doi.org/10.1007/ s10551-012-1298-2

6. Bawafaa, E. (2014). The Influence of Resonant Leadership and Structural Empowerment on the Job Satisfaction of Registered Nurses (Master's thesis). The University of Western Ontario. Retrieved from https://ir.lib.uwo.ca/ etd/2164

7. Bawafaa, E., Wong, C. A., \& Laschinger, H. (2015). The influence of resonant leadership on the structural empowerment and job satisfaction of registered nurses. Journal of Research in Nursing, 20(7), 610-622. https://doi. org/10.1177/1744987115603441

8. Borghei, R., Jandaghi, G., Matin, H. Z., \& Dastani, N. (2010). An examination of the relationship between empowerment and organizational commitment. International Journal of Human Sciences, 7(2).

9. Cummings, G. G., MacGregor, T., Davey, M., Lee, H., Wong, C. A., Lo, E., Muise, M., \& Stafford, E. (2010). Leadership Styles and Outcome Patterns for the Nursing Workforce and Work Environment: A Systematic Review. International Journal of Nursing Studies, 47(3), 363-385. http://dx.doi.org/10.1016/j. ijnurstu.2009.08.006

10. Danish, R. Q., Sidra, R., \& Farid, A. (2013). Effect of Perceived Organizational Support and Work Environment on Organizational Commitment; Mediating Role of Self-Monitoring. Advances in Economics and Business, 1(4), 312-317. http://doi.org/10.13189/ aeb.2013.010402

11. Darwish, A. Y. (2000). Organizational commitment and job satisfaction as predictors of attitudes toward organization change in a non-western setting. Personnel Review, 29 (5-6), 6-25.

12. DeTienne, D. R. (2010). Entrepreneurial exit as a critical component of the entrepreneurial process: Theoretical development. Journal of Business Venturing, 25(2), 203-215. https://doi.org/10.1016/j. jbusvent.2008.05.004

13. Ferreira, L. (2020). Advancing Group Emotional Intelligence through Resonant Leadership and Exploring the Effect on Group Effectiveness (Master's thesis)
Stellenbosch University. Retrieved from https://5dok.net/document/ oy851w4y-advancing-emotionalintelligence-resonant-leadership-exploring-effect-effectiveness.html

14. Forrester, R. (2000). Empowerment: rejuvenating a potent idea. Academy of Management Executive, 14(3), 67-81. https://doi.org/10.5465/ ame.2000.4468067

15. García-Juan, B., Escrig-Tena, A. B., \& Roca-Puig, V. (2019). The empowerment-organizational performance link in local governments. Personnel Review 48(1), 118-140. http://dx.doi. org/10.1108/PR-09-2017-0273

16. Gardner, D. G., Pierce, J. L., \& Peng, H. (2021). Social exchange and psychological ownership as complementary pathways from psychological contract fulfillment to organizational citizenship behaviors. Personnel Review, 50(6), 1479-1494. https://doi.org/10.1108/PR-122019-0688

17. Goleman, D., Boyatzis, R., \& McKee, A. (2002). Primal leadership: Learning to lead with emotional intelligence. Harvard Business School Press.

18. Hameed, Z., Khan, I. U., Sheikh, Z., Islam, T., Rasheed, M. I., \& Naeem, R. M. (2019). Organizational justice and knowledge sharing behavior: the role of psychological ownership and perceived organizational support. Personnel Review, 48(3), 748-773. https://doi.org/10.1108/ PR-07-2017-0217

19. Han, T-S., Chiang, H-H., \& Chang, A. (2010). Employee participation in decision making, psychological ownership and knowledge sharing: mediating role of organizational commitment in Taiwanese hightech organizations. The International Journal of Human Resource Management, 21(12), 2218-2233. 
http://dx.doi.org/10.1080/09585192. 2010.509625

20. Hanaysha, J. (2016). Testing the Effects of Employee Empowerment, Teamwork, and Employee Training on Employee Productivity in Higher Education Sector. International Journal of Learning \& Development, 6(1), 164-178. http://doi. org/10.5296/ijld.v6i1.9200

21. Iverson, R. D. (1996). Employee Acceptance of Organizational Change: The Role of Organizational Commitment. The International Journal of Human Resource Management, 7(1), 122-149. https://doi. org/10.1080/09585199600000121

22. Kline, R. B. (2005). Principles and Practice of Structural Equation Modeling. New York: Guilford Press.

23. Laschinger, H. K. S., Finegan, J., Shamian, J., \& Wilk, P. (2001). Impact of structural and psychological empowerment on job strain in nursing work settings: expanding Kanter's model. Journal of Nursing Administration, 31(5), 260-272. https://doi. org/10.1097/00005110-20010500000006

24. Laschinger, H. K., Wong, C. A., Cummings, G. G., \& Grau, A. L. (2014). Resonant leadership and workplace empowerment: The value of positive organizational cultures in reducing workplace incivility. Nursing Economics, 32(1), 5-16. Retrieved from https://pubmed.ncbi. nlm.nih.gov/24689153/

25. Lu, L., Liu, J., \& Zhao, N. (2017) Why employees stay: the roles of psychological ownership, territoriality and work relationship closeness in affecting employee turnover intention. Frontiers of Business Research in China, 11(1), 1-16. https://doi.org/10.1186/ s11782-017-0010-X

26. Mathieu, J. E., \& Zajac, D. M. (1990). A review and meta-analysis of the antecedents, correlates, and consequences of organizational commitment. Psychological Bulletin, 108(2), 171-194. http://dx.doi. org/10.1037//0033-2909.108.2.171

27. Mayhew, M. G., Ashkanasy, N. M., Bramble, T., \& Gardner, J. (2007).
A Study of the Antecedents and Consequences of Psychological Ownership in Organizational Settings. Journal of Social Psychology, 147(5), 477-500. https://doi. org/10.3200/socp.147.5.477-500

28. Meyer, J. P., \& Allen, N. J. (1991). A three-component conceptualization of organizational commitment. Human Resource Management Revision, 1(1), 61-89. https://doi. org/10.1016/1053-4822(91)90011-Z

29. Meyer, J. P., \& Allen, N. J. (1997) Commitment in the Workplace. Thousand Oaks, CA: Sage publications.

30. Mubarak, F., Noor, A., \& Nunn, S. (rev.ed). (2018). Effect of authentic leadership on employee creativity in project-based organizations with the mediating roles of work engagement and psychological empowerment. Cogent Business \& Management, 5(1). https://doi.org/1 $0.1080 / 23311975.2018 .1429348$

31. Nielsen, F. J., \& Host, V. (2000) The Path to Service Encounter Performance in Public and Private 'Bureaucracies'. The Service Industries Journal, 20(1), 40-60. https://doi. org/10.1080/02642060000000003

32. Peng, H. (2013). Why and when do people hide knowledge? Journal of Knowledge Management, 17(3), 398-415. https://doi.org/10.1108/ JKM-12-2012-0380

33. Pierce, J. L., Kostova, T., \& Dirks, K. T. (2001). Toward a theory of psychological ownership in organizations. Academy of Management Review, 26(2), 298-310. https://doi.org/10.2307/259124

34. Pierce, J. L., Kostova, T., \& Dirks, K. T. (2003). The state of psychological ownership: Integrating and extending a century of research. Review of General Psychology, 7(1), 84-107. https://doi. org/10.1037/1089-2680.7.1.84

35. Ramos-Villarreal, J., \& Holland, G. (2011). University Students' Development of Emotional Intelligence Skills for Leadership. American Journal of Business Education, 4(3), 47-54. https://doi. org/10.19030/ajbe.v4i3.4112

36. Sabir, M. S., \& Khan, M. A. (2011) Impact of Leadership Style on Organization Commitment: In A
Mediating Role of Employee Values. Journal of Economics and Behavioral Studies, 3(2), 145-152. https://doi. org/10.22610/jebs.v3i2.265

37. Spreitzer, G. M. (1995). Psychological empowerment in the workplace: Dimensions, measurement, and validation. Academy of Management Journal, 38, 1442-1465.

38. Squires, M., Tourangeau, A., Laschinger, H. K. S., \& Doran, D. (2010). The link between leadership and safety outcomes in hospitals. Journal of Nursing Management, 18(8), 914-925. https://doi.org/10.1111/j.13652834.2010.01181.x

39. Thomas, K. W., \& Velthouse, B. A. (1990). Cognitive elements of empowerment: An interpretive model of intrinsic task motivation. Academy of Management Review, 15(4), 666-681. Retrieved from https://psycnet.apa.org/ doi/10.2307/258687

40. Van Dyne, L., \& Pierce, J. L. (2004). Psychological ownership and feelings of possession: Three field studies predicting employee attitudes and organizational citizenship behavior. Journal of Organizational Behavior, 25(4), 439459. https://doi.org/10.1002/job.249

41. Wagner, J. (2010). Exploring the Relationships Among Spirit at Work, Structural and Psychological Empowerment, Resonant Leadership, Job Satisfaction, and Organizational Commitment in the Health Care Workplace. University of Alberta.

42. Wagner, J. I., Warren, S., Cummings, G., Smith, D. L., \& Olson, J. K. (2013). Resonant Leadership, Workplace Empowerment and Spirit at Work: Impact on RN Job Satisfaction and Organizational Commitment. Canadian Journal of Nursing Research, 45(4), 108-128. https://doi. org/10.1177/084456211304500409

43. Weiss, E. M. (1999). Perceived workplace conditions and first-year teachers morale, career choice commitment and planned retention: a secondary analysis. Teaching and Teacher Education, 15(8), 861-879. https://doi.org/10.1016/S0742051X(99)00040-2 